\title{
Yield, Yield Distribution, and Forage Quality of Warm-Season Perennial Grasses Grown for Pasture or Biofuel in the Southern Great Plains
}

\author{
James K. Rogers, Frank J. Motal, and Jagadeesh Mosali \\ Agricultural Division, The Samuel Roberts Noble Foundation, 2510 Sam Noble Parkway, Ardmore, OK 73401, USA \\ Correspondence should be addressed to James K. Rogers, jkrogers@noble.org
}

Received 28 October 2011; Accepted 20 November 2011

Academic Editors: M. Diaz Ravina, T. E. Fenton, B. Kindiger, and J. Ransom

Copyright ( 92012 James K. Rogers et al. This is an open access article distributed under the Creative Commons Attribution License, which permits unrestricted use, distribution, and reproduction in any medium, provided the original work is properly cited.

Fifteen introduced and native warm-season perennial grasses were evaluated for yield, yield distribution, and quality in southcentral Oklahoma. These grasses have production potential for forage and/or biofuel. Each was harvested one to four times per year. "Alamo" switchgrass (Panicum virgatum) had a two-year average dry matter yield of $17690 \mathrm{~kg} \mathrm{ha}^{-1}$. Over $1 / 3$ of this production occurred in May with a crude protein (CP) range of $97-115 \mathrm{~g} \mathrm{~kg}^{-1}$. Alamo's high yield potential and early spring growth make it attractive for spring forage production and fall biomass production. Other grasses with two-year average dry matter yields over $11200 \mathrm{~kg} \mathrm{ha}^{-1}$ and $1 / 3$ of yearly production occurring early in the growing season that have potential dual purpose use include "Selection 75" kleingrass (Panicum coloratum), "Midland 99" bermudagrass (Cynodon dactylon), johnsongrass (Sorghum halepense), "Carostan” flaccidgrass (Pennisetum flaccidum), and "Ermelo" weeping lovegrass (Eragrostis curvula).

\section{Introduction}

Beef cattle production is a major agricultural enterprise in south-central Oklahoma and the southern Great Plains. Large acreages are currently established in both native and introduced warm-season perennial grasses that support beef cattle production. According to the 2007 Census of Agriculture, Oklahoma ranks fifth nationally in cattle and calves and fourth in acres in forage, while Texas ranks number one in both of these categories. The Energy Independence and Security Act of 2007 calls for 136 billion liters of biofuels to be produced from renewable resources in the US by 2022 with just under half to be produced from a cellulosic biomass source such as switchgrass [1]. To meet the demand for cellulosic ethanol production called for in The Energy Independence and Security Act of 2007, could require the conversion of acreage currently established in perennial grasses to higher biomass producing grass species such as switchgrass. There is currently an economic incentive for producers to maintain their production practices in beef cattle; however, to reach the biofuel production goals stated in the Energy Independence and Security Act, with continued emphasis on the use of switchgrass as the primary source of renewable biofuel stock a shift from current grass production systems to switchgrass production may be required. Producers may be willing to shift production practice if they understand that what they grow for biofuel could also be used for forage production to support grazing or haying.

The objective of the study was to evaluate differences in biomass production of fifteen warm-season perennial grasses that are currently grown or have the potential to be grown in Oklahoma, Texas, and other regions and compare their biomass production to the switchgrass variety "Alamo" which is currently used as an industry standard for biomass production for biofuel. A second objective of the study was to determine the distribution of yield of these grasses and identify if opportunities exist for both forage and biofuel production. A third objective was to compare the seasonal quality of these grasses. 


\section{Materials and Methods}

2.1. Species. Native grass species in this study were two switchgrass cultivars, "Alamo" and "Blackwell" and "Lometa" indiangrass (Sorghastrum nutans). Switchgrass is an indigenous species that can be found growing over the eastern two-thirds of the US, Central America, and southern Canada [2]. "Alamo" switchgrass is a "lowland" ecotype released by the Texas A\&M experiment station and the Natural Resources Conservation Service (NRCS) in 1978 [3]. In general, lowland switchgrass is taller, leaves are coarser, and they tend to be more rust resistant than their upland counterpart. Lowland switchgrass can have a very strong bunch-type growth habit if left unharvested and tends to be very rapidly growing. Lowland switchgrass is often found on floodplains and similar areas with highmoisture availability [4]. "Blackwell" is an "upland" ecotype switchgrass developed from a selection from seed harvested in 1934 from a single plant growing in a native prairie near Blackwell, OK, USA. It is of medium height and was released in 1944 cooperatively by the Kansas State Experiment station and NRCS plant materials center at Manhattan, KS, USA [5]. Upland switchgrass ecotypes can be found in upland areas that are not subject to flooding [4]. Though shorter and not as rapidly growing, uplands tend to be more cold tolerant and are often found as a component of the native grass prairies in more northern latitudes [6]. "Lometa" indiangrass is a variety released in 1981 by Texas A\&M Experiment Station and NRCS plant materials center at Knox City, TX, USA [3] originating from selections near Lometa, TX, USA. Indiangrass has a bunch growth habit with short rhizomes. Its spring growth initiation is similar to switchgrass; however; it exhibits a later maturity than switchgrass [4].

The remaining entries in the study were introduced grasses. "Common" blue panicgrass (Panicum antidotale) is a rhizomatous bunchgrass native to southern Asia [7]. "Common" Dallisgrass (Paspalum dilatatum) is native to South America and is a weak bunchgrass with short rhizomes. "Ermelo" weeping lovegrass was developed from a South African strain and released by the Texas Research Foundation [8]. "Morpa" weeping lovegrass was released by the Oklahoma Agricultural Experiment Station and USDA, ARS. [8].Weeping lovegrass is a strong bunchgrass and well adapted to sandy soils with low water-holding capacity [7]. "Carostan" flaccidgrass was released by the North Carolina Agricultural Experiment Station in 1987. Flaccidgrass is native to central Asia, and it has been grown successfully along the east coast, Arkansas, New Mexico, and Oklahoma [9]. "Common" johnsongrass is a native of North Africa, South Asia, and southern Europe and was introduced into the US around 1830 [10]. It is very adapted to clay soils and can be an aggressive invader. Under close continuous grazing, johnsongrass stands become less vigorous [11]. "Selection 75" kleingrass released by Texas A\&M Experiment Station and NRCS in 1968 [3]. Kleingrass is a bunchgrass from South Africa and is adapted to soils ranging from sandy loam to clay [7]. "Midland 99" bermudagrass was released in 1999 by the Oklahoma, Kansas, Arkansas, and Missouri Agricultural Experiment Stations, the Samuel Roberts Noble Foundation, and USDA-ARS [12]. Bermudagrass is well adapted to sandy loam soils and can withstand heavy grazing pressure. "Plains" old world bluestem (Bothriochloa ishaemum) was released in 1972 by the Oklahoma Agricultural Experiment Station and USDA-ARS from lines originating in southcentral Asia. It is a bunchgrass with good drought tolerance [13], but it is an aggressive competitor with indigenous grass species [14]. "Pensacola" bahiagrass (Paspalum notatum) was introduced into the US from South America in the late 1930s and is the most widely grown bahiagrass in the US. It can form a dense sod and is often a component of coastal plains pastures. "AU Sand Mountain" bahiagrass is a release from Auburn University from a selection of "Pensacola". It has been shown to be more winter hardy than other bahiagrass varieties in the Piedmont regions of the southeast [15]. "WW-B. Dahl" (Bothriochloa bladhii) old world bluestem was released in 1994 by USDA-ARS, USDA-SCS, Texas Tech University, and the Texas Agricultural Experiment Station from a selection made in India. It is a bunchgrass with an upright growth habit [16].

2.2. Study Site Description. The study was conducted in 2004 and 2005 at the Noble Foundation's Pasture Demonstration Farm near Ardmore, OK, USA ( $34^{\circ} 23^{\prime}$ lat., $-97^{\circ} 21^{\prime}$ long.). The soil at the location is a Wilson silt loam (Fine, smectitic, thermic Oxyaquic Vertic Haplustalfs).

Plots were originally established in May, 1998 into a randomized complete block design with three replications and a plot size of $3.0 \mathrm{~m} \times 6.0 \mathrm{~m}$. Incorporated prior to planting, the plot area received $2.24 \mathrm{Mg} \mathrm{ha}^{-1}$ of $100 \%$ effective calcium carbonate equivalent lime and $40.0 \mathrm{~kg} \mathrm{Nha}^{-1}$ and $103.0 \mathrm{~kg} \mathrm{P}_{2} \mathrm{O}_{5} \mathrm{ha}^{-1}$. From 1999 to 2003 , plots were harvested once per year at the end of the growing season. In April, 2004, the plot area was soil-tested to a sampling depth of $152 \mathrm{~mm}$. Based on the results of the soil report, $78.0 \mathrm{~kg} \mathrm{~N} \mathrm{ha}^{-1}, 52.0 \mathrm{~kg}$ $\mathrm{P}_{2} \mathrm{O}_{5} \mathrm{ha}^{-1}$, and $67.0 \mathrm{~kg} \mathrm{~K}_{2} \mathrm{O} \mathrm{ha}^{-1}$ were applied to the plot area in May. In addition, the plot area was sprayed for broadleaf weeds with $5.0 \mathrm{l} \mathrm{ha}^{-1}$ of 2, 4-dichlorophenoxy acid (2, 4-D). In April of 2005, the plot area was soil-tested to a $152 \mathrm{~mm}$ depth. Based on soil test results, $78 \mathrm{~kg} \mathrm{~N}^{-1}$ was applied to the plot area in May. No additional fertilizer amendments were applied. The plot area was sprayed in May, 2005 for broadleaf weeds with $5.01 \mathrm{ha}^{-1}$ of $2,4-\mathrm{D}$.

2.3. Data Collection. Plots were harvested by species when each species reached the boot stage of reproductive development. This resulted in four harvest dates in 2004 of May 25, June 14, August 03, and September 16. Harvest dates in 2005 were May 23, June 30, August 11, and October 5. Plots were harvested using a Hege plot harvester (Wintersteiger, Inc., Salt Lake City, UT, USA) with a $1.52 \mathrm{~m}$ wide sickletype cutter. A $1.52 \mathrm{~m} \times 6.0 \mathrm{~m}$ strip was harvested from the center of each plot, and individual fresh plot weights recorded. A subsample from each plot was collected within each replication. All samples were dried in a forced air oven at $50^{\circ} \mathrm{C}$ for 3 to 4 days until they reached a constant weight and were then weighed. Dry matter was determined, and yield was reported on a DM basis. The subsamples were then 
combined within the same species and variety across replications, and one representative sample collected from the combined replications was used for quality determination. Subsamples were ground in a Wiley mill (Thomas Wiley Laboratory Mill, Thomas Scientific, Swedesboro, NJ, USA) to pass a $1 \mathrm{~mm}$ screen. Subsamples were analyzed for crude protein $(\mathrm{CP})$ and acid detergent fiber (ADF) using the Foss 6500 NIRS instrument. The samples were scanned using Foss ISIScan software (FOSS NIR Systems, Inc., Laurel, MD, USA). Forage compositional analysis was determined using the Foss Commercial 2001 Grass and Legume Hay prediction equation. The CP mean, standard error of validation, and $r^{2}$ for the equation used were $17.1 \%, 0.69 \%$, and $0.98 \%$ respectively. The ADF mean, standard error of validation, and $r^{2}$ for the equation used were $35.1 \%, 1.3 \%$, and $0.96 \%$, respectively. These equations were then used to predict $\mathrm{CP}$ and ADF values for all samples. The total digestible nutrient (TDN) values were calculated using the Penn State equation: $\mathrm{NEL}=1.044-(.0119 * \mathrm{ADF})$ and $\mathrm{TDN}=4.898+(89.796 *$ NEL).

2.4. Statistical Analysis. Yield data were analyzed using analysis of variance by the PROC GLM procedure of SAS (SAS Institute Inc., Cary, NC, USA) following a randomized complete block design with replication treated as a random effect. Yield means were separated at $P=0.05$. A variety by year interaction for yield was significant $(P<0.05)$, and therefore results are presented by year. Standard error of the mean was generated for quality using PROC MEANS. All quality concentration data are reported on a dry matter basis.

\section{Results and Discussion}

3.1. Precipitation. Total precipitation varied little from the long-term average for 2004 and 2005 and was adequate to produce good yields in both years. In 2005, a drier than normal period from March-June followed by above normal precipitation from July-August resulted in an October final harvest for most grasses compared to final harvest in September 2004 (Table 1).

3.2. Forage Yield. In 2004, there was no significant difference in total forage yield among "Alamo" switchgrass, johnsongrass, "Selection 75" kleingrass, and "Carostan" flaccidgrass (Table 2) with "Alamo" harvested twice and johnsongrass, kleingrass, and flaccidgrass harvested three times. In 2005, "Alamo" switchgrass produced greater biomass than other grasses in the study over three harvests (Table 3 ). Johnsongrass, "Selection 75" kleingrass, and "Carostan" flaccidgrass were similar in yield and were harvested three times in 2005 (Table 3). "Alamo" switchgrass exhibited higher yields at the May harvest in both years of the study compared to other grasses (Tables 2 and 3). "Alamo" switchgrass has also been found to be among the highest yielding grasses in other studies in Oklahoma and Kansas $[17,18]$. "Alamo" has performed well in both one- and two-cut systems across multiple locations in the Southeast
TABLE 1: Monthly precipitation during the years of 2004 and 2005 and historical long-term average precipitation near Ardmore, OK, USA.

\begin{tabular}{lccc}
\hline Month & $\begin{array}{c}\text { 102-year average } \\
(\mathrm{mm})^{\mathrm{a}}\end{array}$ & $\begin{array}{c}2004 \\
(\mathrm{~mm})\end{array}$ & $\begin{array}{c}2005 \\
(\mathrm{~mm})\end{array}$ \\
\hline January & 45.2 & 30.0 & 122.0 \\
February & 52.3 & 94.0 & 50.0 \\
March & 74.0 & 37.0 & 18.5 \\
April & 102.4 & 108.5 & 6.6 \\
May & 132.3 & 14.0 & 90.7 \\
June & 101.1 & 206.0 & 63.7 \\
July & 69.0 & 140.2 & 130.3 \\
August & 87.1 & 51.0 & 159.8 \\
September & 91.2 & 7.9 & 65.3 \\
October & 94.2 & 169.7 & 87.9 \\
Total & 848.8 & 858.3 & 794.5 \\
\hline
\end{tabular}

aklahoma Mesonet weather data.

and out yielding upland types as well as the lowland type, "Kanlow" [19]. "Alamo" has also demonstrated longterm yield persistence in an Auburn University planting established in 1988 which has had average yields of $23.1 \mathrm{Mg}$ $\mathrm{ha}^{-1}$ over 13 years [20], but it should be noted that Auburn University is located in a $1321 \mathrm{~mm}$ per year rainfall zone. By contrast, "Alamo" switchgrass yields dropped in a twocut system when harvested in July and again in October [21]. In our study, "Alamo" yields remained consistent with multiple harvests within years and an average of 75 days rest prior to the second cutting. "Midland 99" bermudagrass and "Ermelo" weeping lovegrass produced total yields in excess of $12.6 \mathrm{Mg} \mathrm{ha}^{-1}$ in both years of the study over three harvests.

3.3. Forage Quality. Large quality differences were not apparent for grasses evaluated in the study (Tables 4 and 5). The exceptions were "Pensacola" bahiagrass and "WW-B. Dahl" old world bluestem which exhibited CP levels below $50 \mathrm{~g} \mathrm{~kg}^{-1}$ in the final harvest of 2005. In 2004, their quality had been similar to other grasses in the study. Mean CP declined $46 \%$ from May to August in both years of the study. In the May harvest of 2004, CP of all grasses harvested was above $108 \mathrm{~g} \mathrm{~kg}^{-1}$ except, "Midland 99" bermudagrass which was $86.0 \mathrm{~g} \mathrm{~kg}^{-1}$ (Table 4). CP at or above $108 \mathrm{~g} \mathrm{~kg}^{-1}$ would be a sufficient protein level to support a $272.4 \mathrm{~kg}$ stocker daily gain of $.681 \mathrm{~kg}$; however, TDN percent in the grasses was limiting and would need supplementation [22]. In May 2005, CP of the grasses is expected to support good stocker daily gains with the exception of "Alamo" switchgrass and "johnsongrass" which had CP levels slightly below $108 \mathrm{~g} \mathrm{~kg}^{-1}$ (Table 5). TDN of the grasses is limiting with expected stocker daily gains based on nutrient analysis of .454$.681 \mathrm{~kg} /$ day. The exception was "Midland 99" bermudagrass which could support a $272.4 \mathrm{~kg}$ stocker daily gain of $.681 \mathrm{~kg}$ [22]. The forage quality of grasses measured in May meets the nutritional requirements of mature beef cows for the first 90 days after calving. Even though forage quality begins to decline from May to June, the forage quality of these grasses 
TABLE 2: Dry matter yield by harvest month of fifteen warm-season perennial grasses in 2004 near Ardmore, OK, USA.

\begin{tabular}{|c|c|c|c|c|c|}
\hline \multirow{2}{*}{ Species } & \multicolumn{5}{|c|}{ Yield $\left(\mathrm{kg} \mathrm{ha}^{-1}\right)$} \\
\hline & May & June & Aug. & Sept. & Total \\
\hline Alamo switchgrass & $6129^{\mathrm{a} \dagger}$ & - & $10012^{\mathrm{a}}$ & - & $16140^{\mathrm{a}}$ \\
\hline Blue panicgrass & - & - & $3415^{\mathrm{e}}$ & 1785 & $5200^{\mathrm{fg}}$ \\
\hline Blackwell switchgrass & - & $9385^{\mathrm{a}}$ & - & - & $9385^{\text {de }}$ \\
\hline Dallisgrass & - & $4245^{\mathrm{bc}}$ & 3158 & - & $7403^{\text {ef }}$ \\
\hline Ermelo weeping lovegrass & $3568^{\mathrm{bc}}$ & - & 7036 & 2305 & $12909^{\mathrm{bc}}$ \\
\hline Carostan flaccidgrass & $4519^{\mathrm{bc}}$ & - & 8467 & 1803 & $14790^{\mathrm{ab}}$ \\
\hline Johnsongrass & $4712^{\mathrm{b}}$ & - & 9260 & 1665 & $15637^{\mathrm{ab}}$ \\
\hline Selection 75 kleingrass & $4375^{\mathrm{bc}}$ & - & 8829 & 1982 & $15186^{\mathrm{ab}}$ \\
\hline Lometa indiangrass & - & $7000^{\mathrm{ab}}$ & - & - & $7000^{\mathrm{ef}}$ \\
\hline Midland 99 bermudagrass & $3869^{\mathrm{bc}}$ & - & 7323 & 1809 & $13000^{\mathrm{bc}}$ \\
\hline Morpa weeping lovegrass & $3276^{\mathrm{c}}$ & - & 6281 & 1988 & $11545^{\mathrm{cd}}$ \\
\hline Pensacola bahiagrass & - & $3503^{c}$ & 5827 & 2199 & $11529^{\mathrm{cd}}$ \\
\hline Plains bluestem & - & $3797^{\mathrm{bc}}$ & - & - & $3797^{g}$ \\
\hline Sand Mountain bahiagrass & - & - & - & 2498 & $2498^{\mathrm{g}}$ \\
\hline WW-B. Dahl old world bluestem & - & $5192^{\mathrm{bc}}$ & - & - & $5192^{\mathrm{fg}}$ \\
\hline Mean & 4350 & 5520 & 6961 & 2004 & 10081 \\
\hline
\end{tabular}

- indicates that the species was not harvested that month.

${ }^{\dagger}$ Means within column by the same letter are not significantly different at $P \leq 0.05$.

TABLE 3: Dry matter yield by harvest month of fifteen warm-season perennial grasses in 2005 near Ardmore, OK, USA.

\begin{tabular}{|c|c|c|c|c|c|}
\hline \multirow{2}{*}{ Species } & \multicolumn{5}{|c|}{ Yield $\left(\mathrm{kg} \mathrm{ha}^{-1}\right)$} \\
\hline & May & June & Aug. & Oct. & Total \\
\hline Alamo switchgrass & $8926^{\mathrm{a} \dagger}$ & - & $6757^{a}$ & $3557^{\text {cd }}$ & $19240^{\mathrm{a}}$ \\
\hline Blue panicgrass & $996^{\mathrm{e}}$ & $1129^{c}$ & $4691^{\mathrm{b}}$ & $3023^{\mathrm{d}}$ & $9839^{\text {cde }}$ \\
\hline Blackwell switchgrass & $5173^{\mathrm{bc}}$ & - & $3908^{\mathrm{bc}}$ & - & $9081^{\mathrm{de}}$ \\
\hline Dallisgrass & - & $4685^{\mathrm{a}}$ & - & $5020^{\mathrm{bc}}$ & $9705^{\text {cde }}$ \\
\hline Ermelo weeping lovegrass & $5444^{\mathrm{b}}$ & - & $4039^{\mathrm{bc}}$ & $3195^{d}$ & $12678^{\text {bcde }}$ \\
\hline Carostan flaccidgrass & $4986^{\mathrm{bc}}$ & - & $4834^{\mathrm{ab}}$ & $2212^{\mathrm{d}}$ & $12032^{\text {bcde }}$ \\
\hline Johnsongrass & $4855^{\mathrm{bc}}$ & - & $3195^{\mathrm{bc}}$ & $2462^{\mathrm{d}}$ & $10512^{\text {bcde }}$ \\
\hline Selection 75 kleingrass & $6030^{\mathrm{b}}$ & - & $5189^{\mathrm{ab}}$ & $2751^{\mathrm{d}}$ & $13970^{\mathrm{b}}$ \\
\hline Lometa indiangrass & - & $5392^{\mathrm{a}}$ & - & $5677^{\mathrm{ab}}$ & $11069^{\text {bcde }}$ \\
\hline Midland 99 bermudagrass & $5970^{\mathrm{b}}$ & - & $4445^{\mathrm{b}}$ & $2951^{\mathrm{d}}$ & $13366^{\mathrm{bc}}$ \\
\hline Morpa weeping lovegrass & $4201^{\mathrm{cd}}$ & - & $3862^{\mathrm{bc}}$ & $2854^{\mathrm{d}}$ & $10917^{\text {bcde }}$ \\
\hline Pensacola bahiagrass & $3182^{\mathrm{d}}$ & $1514^{\mathrm{bc}}$ & $3640^{\mathrm{bc}}$ & $2778^{d}$ & $11114^{\text {bcde }}$ \\
\hline Plains bluestem & - & $4311^{\mathrm{ab}}$ & - & $3141^{\mathrm{d}}$ & $7452^{\mathrm{e}}$ \\
\hline Sand Mountain bahiagrass & $2785^{\mathrm{d}}$ & - & $2221^{\mathrm{c}}$ & $2561^{\mathrm{d}}$ & $7567^{\mathrm{e}}$ \\
\hline WW-B. Dahl old world bluestem & - & $4688^{\mathrm{a}}$ & - & $7063^{\mathrm{a}}$ & $11751^{\text {bcd }}$ \\
\hline Mean & 4777 & 3620 & 4253 & 3518 & 11353 \\
\hline
\end{tabular}

- indicates that the species was not harvested that month.

${ }^{\dagger}$ Means within column followed by the same letter are not significantly different at $P \leq 0.05$.

would still meet nutritional requirements of gestating cows' from the middle to last $1 / 3$ of pregnancy. In later months of the grazing season supplementation would be required to meet beef cow nutritional demand [22].

3.4. Forage Yield Distribution. Figure 1 is the average twoyear forage distribution based on total average yield of the fifteen warm-season perennial grasses in this study over harvest dates. Greater total yield potential exists with the grasses that have at least $1 / 3$ of their total forage production occurring early in their growing season. These include "Alamo" switchgrass, "Selection 75" kleingrass, "Midland 99" bermudagrass, johnsongrass, "Carostan" flaccidgrass, and "Ermelo" weeping lovegrass. This early season production also offers forage quality sufficient for postpartum mature cows or, with some supplementation, stocker production. After May harvests, 
TABle 4: Dry matter crude protein (CP), total digestible nutrient (TDN), and acid detergent fiber (ADF) by harvest month of fifteen warmseason perennial grasses in 2004 near Ardmore, OK, USA.

\begin{tabular}{|c|c|c|c|c|c|c|c|c|c|c|c|c|}
\hline \multirow{3}{*}{ Species } & \multicolumn{12}{|c|}{$\left(\mathrm{g} \mathrm{kg}^{-1}\right)$} \\
\hline & \multicolumn{3}{|c|}{ May } & \multicolumn{3}{|c|}{ June } & \multicolumn{3}{|c|}{ August } & \multicolumn{3}{|c|}{ September } \\
\hline & $\mathrm{CP}$ & $\mathrm{TDN}$ & $\mathrm{ADF}$ & $\mathrm{CP}$ & TDN & $\mathrm{ADF}$ & $\mathrm{CP}$ & TDN & $\mathrm{ADF}$ & $\mathrm{CP}$ & TDN & $\mathrm{ADF}$ \\
\hline Alamo switchgrass & 115 & 590 & 393 & - & - & - & 43 & 496 & 477 & - & - & - \\
\hline Blue panicgrass & - & - & - & - & - & - & 68 & 512 & 463 & 162 & 646 & 343 \\
\hline Blackwell switchgrass & - & - & - & 79 & 514 & 461 & - & - & - & - & - & - \\
\hline Dallisgrass & - & - & - & 97 & 532 & 445 & 80 & 549 & 430 & - & - & - \\
\hline Ermelo weeping lovegrass & 113 & 574 & 407 & - & - & - & 57 & 539 & 439 & 70 & 569 & 412 \\
\hline Carostanflaccidgrass & 116 & 580 & 402 & - & - & - & 42 & 471 & 500 & 96 & 549 & 430 \\
\hline Johnsongrass & 108 & 576 & 406 & - & - & - & 40 & 479 & 493 & 101 & 590 & 393 \\
\hline Selection 75 kleingrass & 123 & 613 & 372 & - & - & - & 64 & 561 & 419 & 103 & 635 & 353 \\
\hline Lometaindiangrass & - & - & - & 66 & 530 & 447 & - & - & - & - & - & - \\
\hline Midland 99 bermudagrass & 86 & 599 & 385 & - & - & - & 51 & 584 & 398 & 88 & 589 & 394 \\
\hline Morpa weeping lovegrass & 108 & 564 & 416 & - & - & - & 59 & 548 & 431 & 76 & 578 & 404 \\
\hline Pensacola bahiagrass & - & - & - & 104 & 578 & 404 & 84 & 572 & 409 & 86 & 569 & 412 \\
\hline Plains bluestem & - & - & - & 96 & 512 & 463 & - & - & - & - & - & - \\
\hline $\begin{array}{l}\text { Sand Mountain } \\
\text { bahiagrass }\end{array}$ & - & - & - & - & - & - & - & - & - & 121 & 619 & 367 \\
\hline $\begin{array}{l}\text { WW.B-Dahl old world } \\
\text { bluestem }\end{array}$ & - & - & - & 84 & 555 & 442 & - & - & - & - & - & - \\
\hline Mean & 110 & 585 & 397 & 88 & 537 & 441 & 59 & 531 & 446 & 100 & 594 & 390 \\
\hline Standard error $\dagger$ & 4.4 & 6.3 & 5.7 & 5.7 & 10.3 & 9.3 & 4.9 & 12.4 & 11.2 & 9.2 & 11 & 9.8 \\
\hline
\end{tabular}

- indicates that the species was not harvested that month.

†Standard errors are calculated within columns.

TABLE 5: Dry matter crude protein (CP), total digestible nutrient (TDN), and acid detergent fiber (ADF) by harvest month of fifteen warmseason perennial grasses in 2005 near Ardmore, OK, USA.

\begin{tabular}{|c|c|c|c|c|c|c|c|c|c|c|c|c|}
\hline \multirow{3}{*}{ Species } & \multicolumn{12}{|c|}{$\left(\mathrm{g} \mathrm{kg}^{-1}\right)$} \\
\hline & \multicolumn{3}{|c|}{ May } & \multicolumn{3}{|c|}{ June } & \multicolumn{3}{|c|}{ August } & \multicolumn{3}{|c|}{ October } \\
\hline & $\mathrm{CP}$ & TDN & $\mathrm{ADF}$ & $\mathrm{CP}$ & TDN & $\mathrm{ADF}$ & $\mathrm{CP}$ & TDN & $\mathrm{ADF}$ & $\mathrm{CP}$ & TDN & $\mathrm{ADF}$ \\
\hline Alamo switchgrass & 97 & 567 & 414 & - & - & - & 69 & 563 & 419 & 82 & 581 & 395 \\
\hline Blue panicgrass & 171 & 602 & 369 & 194 & 650 & 307 & 91 & 569 & 411 & 52 & 536 & 453 \\
\hline Blackwell switchgrass & 127 & 599 & 370 & - & - & - & 75 & 569 & 411 & - & - & - \\
\hline Dallisgrass & - & - & - & 153 & 606 & 360 & - & - & - & 56 & 516 & 479 \\
\hline Ermelo weeping lovegrass & 110 & 578 & 399 & - & - & - & 76 & 536 & 453 & 63 & 531 & 460 \\
\hline Carostanflaccidgrass & 159 & 599 & 372 & - & - & - & 67 & 551 & 435 & 65 & 544 & 443 \\
\hline Johnsongrass & 101 & 561 & 421 & - & - & - & 71 & 558 & 425 & 69 & 549 & 436 \\
\hline Selection 75 kleingrass & 121 & 581 & 396 & - & - & - & 60 & 546 & 440 & 59 & 560 & 423 \\
\hline Lometaindiangrass & - & - & - & 112 & 581 & 396 & - & - & - & 55 & 525 & 467 \\
\hline Midland 99 bermudagrass & 179 & 645 & 314 & - & - & - & 64 & 579 & 398 & 81 & 593 & 380 \\
\hline Morpa weeping lovegrass & 127 & 592 & 381 & - & - & - & 68 & 543 & 444 & 61 & 530 & 462 \\
\hline Pensacola bahiagrass & 133 & 582 & 395 & 133 & 586 & 389 & 76 & 565 & 417 & 65 & 548 & 438 \\
\hline Plains bluestem & - & - & - & 107 & 551 & 434 & - & - & - & 24 & 481 & 524 \\
\hline $\begin{array}{l}\text { Sand Mountain } \\
\text { bahiagrass }\end{array}$ & 153 & 619 & 347 & - & - & - & 78 & 573 & 405 & 74 & 557 & 426 \\
\hline $\begin{array}{l}\text { WW-B. Dahl old world } \\
\text { bluestem }\end{array}$ & - & - & - & 121 & 608 & 361 & - & - & - & 34 & 520 & 474 \\
\hline Mean & 134 & 593 & 380 & 137 & 597 & 375 & 72 & 559 & 423 & 60 & 541 & 447 \\
\hline Standard error $\dagger$ & 8.4 & 7.2 & 9.2 & 13.2 & 13.5 & 17.4 & 2.5 & 4.1 & 5.3 & 4.3 & 7.5 & 9.6 \\
\hline
\end{tabular}

— indicates that the species was not harvested that month.

t Standard errors are calculated within columns. 


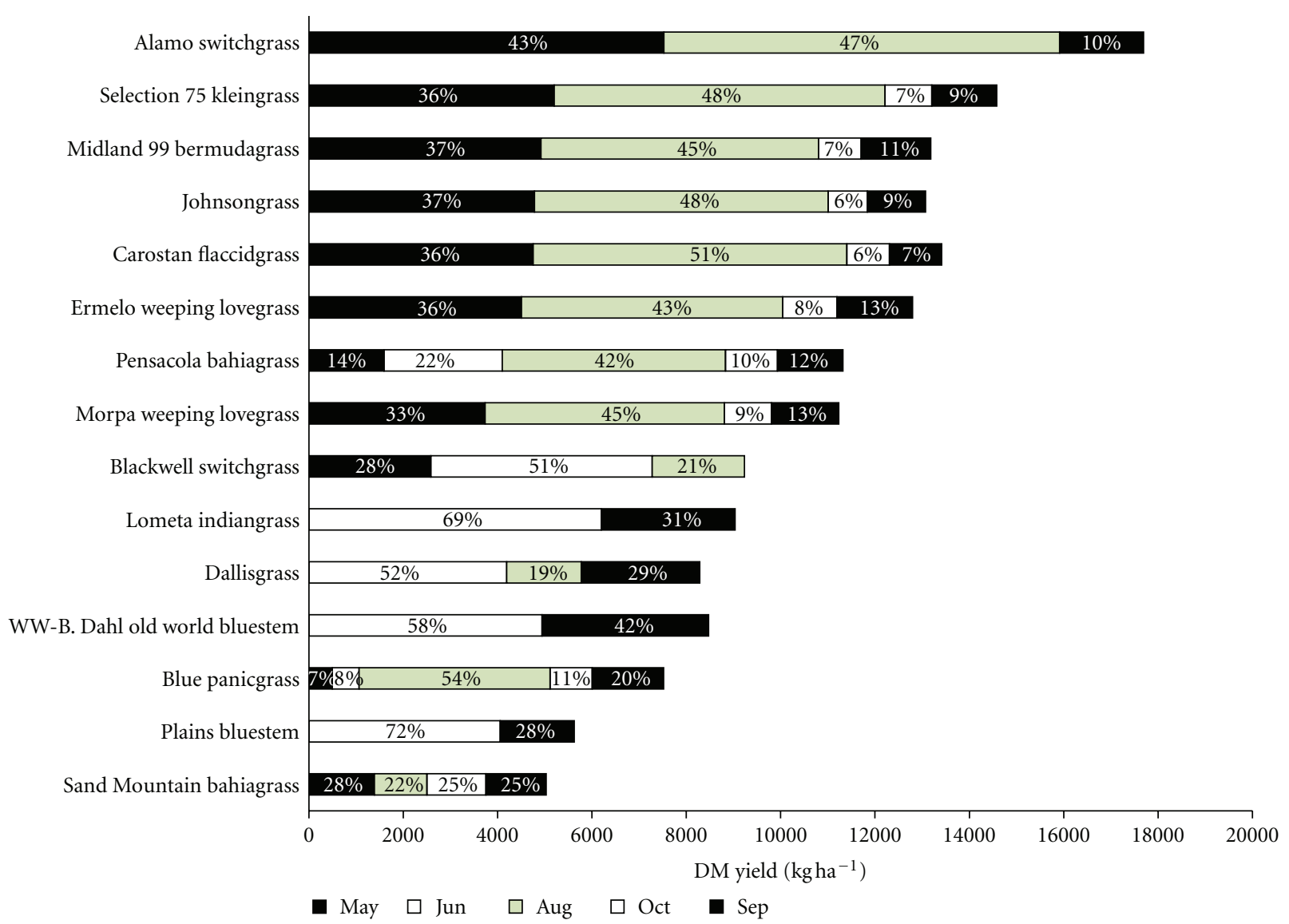

Figure 1: Average monthly percent yield distribution of the total dry matter yield produced from May through October among fifteen warm-season perennial grasses near Ardmore, OK, USA.

these grasses accumulated yields by the August harvest that surpassed May production demonstrating their potential for substantial biomass accumulation by the end of the growing season. Yield distribution of "Alamo" switchgrass is similar to what has been reported in Tennessee [23]. This ability to produce good yields after May would then suggest that these grasses could be used as dual-purpose grasses for both livestock production and cellulosic ethanol production. Other grasses in the study do not display the yield potential or the seasonal distribution to be used as dual-purpose forages.

\section{Conclusions}

"Carostan" flaccidgrass, johnsongrass, and "Selection 75" kleingrass produced similar yields to "Alamo" switchgrass in 2004 but, "Alamo" switchgrass was the highest producing entry in 2005 and would still be considered the standard for biomass production in the region. However, many producers in the southern Great Plains are currently growing bermudagrass, weeping lovegrass, kleingrass, and johnsongrass and are familiar with their establishment and production characteristics. Producers may be willing to produce biomass for biofuel if their existing forage base can be utilized for early season grazing and hay production followed by deferment for biomass accumulation.
Because of the early season production potential and quality of "Carostan" flaccidgrass, johnsongrass, "Midland 99" bermudagrass, "Ermelo" weeping lovegrass "Selection 75" kleingrass, and "Alamo" switchgrass, they could be used as a source of both cellulosic biofuel and forage. Seed sources of flaccidgrass are limited, however flaccidgrass can be sprigged but research into sprigged production and establishment needs to be undertaken. The remaining grasses in the study were slower to initiate spring growth, and the regrowth potential following harvest compared to the top grasses in the study was low which lowered their total yearly production.

As the cellulosic biofuels industry continues to develop, the enzymatic processes used for cellulose extraction will improve thereby expanding potential sources of cellulosic biomass. Based on the results of this study in addition to "Alamo" switchgrass; "Selection 75" kleingrass, "Midland 99" bermudagrass, "Ermelo" weeping lovegrass, "Common" johnsongrass, and "Carostan" flaccidgrass have potential as dual-purpose grasses for forage and biofuel.

\section{References}

[1] D. F. Mooney, R. K. Roberts, B. C. English, D. D. Tyler, and J. A. Larson, "Yield and breakeven price of 'Alamo' switchgrass for biofuels in Tennessee," Agronomy Journal, vol. 101, no. 5, pp. 1234-1242, 2009. 
[2] D. J. Parrish, J. H. Fike, D. I. Bransby, and R. Samson, "Establishing and managing switchgrass as an energy crop," Forage and Grazinglands, 2008.

[3] Natural Resources Conservation Service Plant Materials Center. Celebrating 40 years, Knox City Plant Materials Center, 2010, http://plant-materials.nrcs.usda.gov/pubs/txpmcbr5728.pdf.

[4] L. E. Moser and K. P. Vogel, "Switchgrass, big bluestem, and Indiangrass," in Forages: An Introduction to Grassland Agriculture, R. F. Barnes, C. J. Nelson, M. Collins, and K. J. Moore, Eds., vol. 1, pp. 409-420, Iowa State University Press, Ames, Iowa, USA, 1995.

[5] A. A. Hanson, Grass Varieties in the United States, Agriculture Handbook no. 170, United States Department of Agriculture, 1959.

[6] M. D. Casler, K. P. Vogel, C. M. Taliaferro, and R. L. Wynia, "Latitudinal adaptation of switchgrass populations," Crop Science, vol. 44, no. 1, pp. 293-303, 2004.

[7] P. W. Voigt and W. C. Sharp, "Grasses of the plains and southwest," in Forages: An Introduction to Grassland Agriculture, R. F. Barnes, C. J. Nelson, M. Collins, and K. J. Moore, Eds., vol. 1, pp. 395-408, Iowa State University Press, Ames, Iowa, USA, 1995.

[8] P. W. Voigt, "New varieties of weeping lovegrass through plant evaluation and selection," in Proceedings of the 1st Weeping Lovegrass Symposium, April 1970.

[9] North Carolina Agricultural Research Service, "Carostan flaccidgrass: establishment, adaptation, production management, forage quality, and utilization," Technical Bulletin 313, North Carolina State University, Raleigh, NC, USA, 1998.

[10] W. R. Ocumpaugh and L. E. Sollenberger, "Other grasses for the humid south," in Forages: An Introduction to Grassland Agriculture, R. F. Barnes, C. J. Nelson, M. Collins, and K. J. Moore, Eds., vol. 1, pp. 441-449, Iowa State University Press, Ames, Iowa, USA, 1995.

[11] D. M. Ball, C. S. Hoveland, and G. D. Lacefield, "Warm season grasses," in Southern Forages: Modern Concepts for Forage Crop Management, p. 35, Potash and Phosphate Institute and the Foundation for Agronomic Research, Norcross, Ga, USA, 3rd edition, 2002.

[12] C. M. Taliaferro, J. A. Anderson, and W. L. Richardson, "Registration of "Midland 99" forage bermudagras," Crop Science, vol. 42, pp. 2212-2213, 2002.

[13] C. M. Taliaferro and J. R. Harlan, "Registration of "Plains" bluestem," Crop Science, vol. 13, no. 5, article 580, 1973.

[14] C. D. Schmidt, K. R. Hickman, R. Channell, K. Harmoney, and W. Stark, "Competitive abilities of native grasses and nonnative (Bothriochloa spp.) grasses," Plant Ecology, vol. 197, no. 1, pp. 69-80, 2008.

[15] D. W. Hancock, Varieties of bahiagrass. In Forage species and varieties recommended for Georgia, 2011, http://www .caes.uga.edu/commodities/fieldcrops/forages/species.html.

[16] C. L. Dewald, P. L. Sims, and W. A. Berg, "Registration of "WW-B.Dahl" old world bluestem," Crop Science, vol. 35, article 937, 1995.

[17] M. Haque, F. M. Epplin, and C. M. Taliaferro, "Nitrogen and harvest frequency effect on yield and cost for four perennial grasses," Agronomy Journal, vol. 101, no. 6, pp. 1463-1469, 2009.

[18] J. D. Holman, J. L. Moyer, S. R. Maxwell, and J. L. Martin, "Switchgrass cultivar establishment, iron chlorosis, and biomass yield in southwest and southeast Kansas," Forage and Grazinglands, 2011.
[19] J. H. Fike, D. J. Parrish, D. D. Wolf et al., "Switchgrass production for the upper southeastern USA: influence of cultivar and cutting frequency on biomass yields," Biomass and Bioenergy, vol. 30, no. 3, pp. 207-213, 2006.

[20] S. B. McLaughlin and L. A. Kszos, "Development of switchgrass (Panicum virgatum) as a bioenergy feedstock in the United States," Biomass and Bioenergy, vol. 28, no. 6, pp. 515535, 2005.

[21] M. A. Sanderson, J. C. Read, and R. L. Reed, "Harvest management of switchgrass for biomass feedstock and forage production," Agronomy Journal, vol. 91, no. 1, pp. 5-10, 1999.

[22] D. Lalman, Nutrient Requirements of Beef Cattle, Department of Animal Science, Oklahoma Cooperative Extension Service, Division of Agricultural Sciences and Natural Resources, Oklahoma State University, 2010.

[23] G. Bates, P. Keyser, C. Harper, and J. Waller, Using Switchgrass for Forage, The University of Tennessee Institute of Agriculture, Knoxville, Tenn, USA, 2008. 


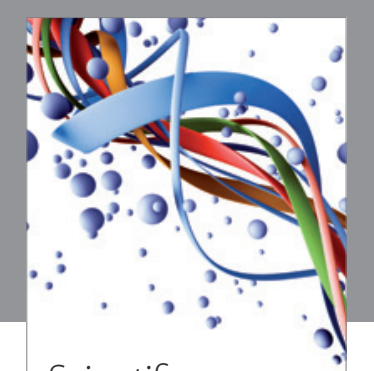

Scientifica

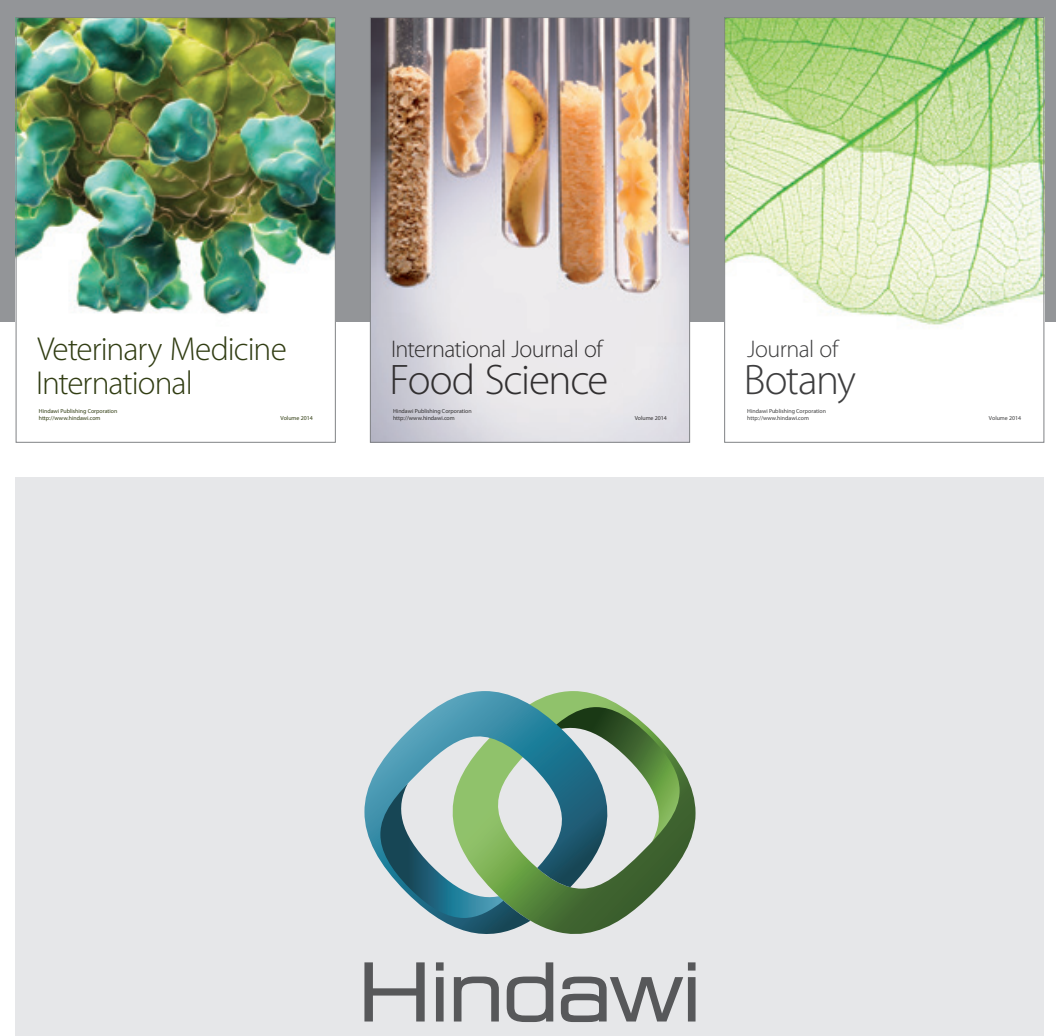

Submit your manuscripts at

http://www.hindawi.com

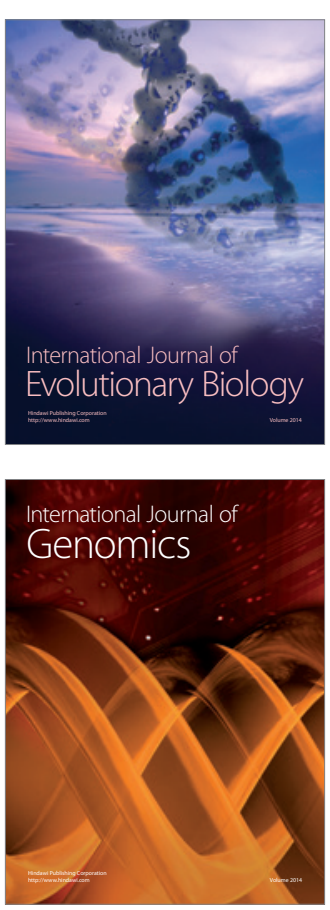
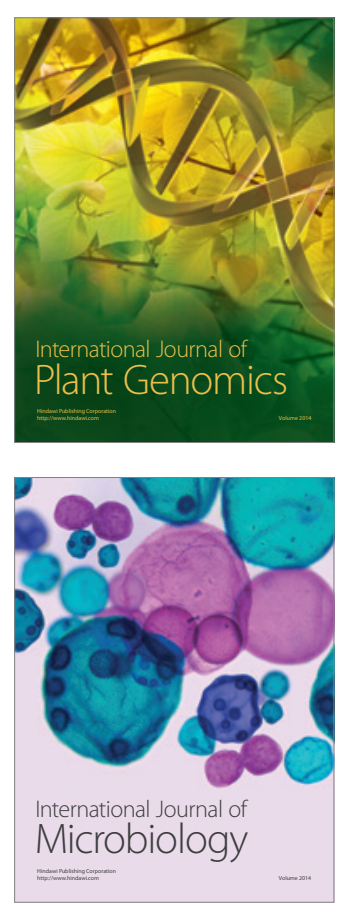

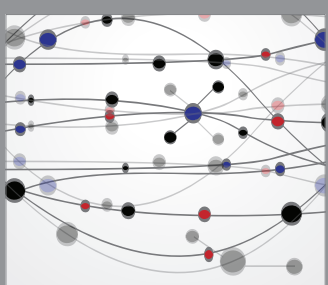

The Scientific World Journal
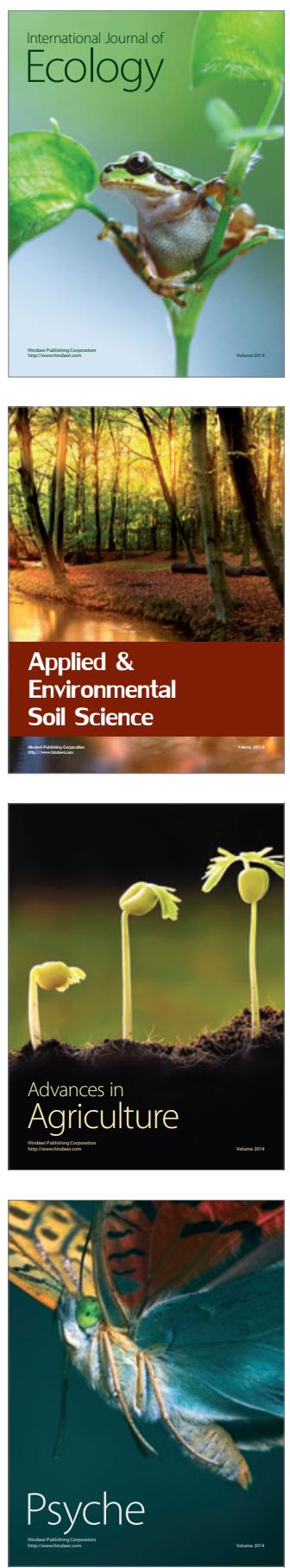